UDK 624.21:7.033.39 (497.6)

\title{
TYPOLOGY OF CULTURAL LANDSCAPE - BRIDGES OF OTTOMAN PERIOD IN PICTURE OF CULTURAL LANDSCAPE
}

\section{Tipologija kulturnog pejzaža - mostovi Osmanskog perioda u slici kulturnog pejzaža}

\author{
Mirna Krpo ${ }^{1}$
}

\begin{abstract}
This work primarily aims to capture and analyze selected new bridge stone structures in the image of the cultural landscape, which occurred in the Ottoman period in the territory of present-day Bosnia and Herzegovina, These bridge structures, regardless of whether they were located directly or connecting routes to the said Roman route, as well as functional - structural miniature sizes or stylish - the aesthetic imbalance have the role specified to fill that void in Bosnia and Herzegovina which is felt in the knowledge of development of those types of buildings.

An analysis of the historical development of bridges leads us in history where we can clearly recognize, on what is based, the maximum utilitarianism bridges in general. Through presented examples we confirm the universality of the object that without certain stylistic affiliation, which were built by hands and knowledge of local builders, however, do not disturb the landscape, but on the contrary, they complement each other, and create a special harmony of space.
\end{abstract}

Key words: Bridge structure, cultural landscape, the Ottoman period, landscape of the bridges

\section{INTRODUCTION - Uvod}

.... "Of all the things a man in the prime of life builds up, and nothing in my eyes is better and more valuable than bridges. They are more important than houses, brighter than the temples, because they are intended to be used by more people, each and every equal to, useful, always built meaningfully, to the point where it crosses the

\footnotetext{
${ }^{1}$ Faculty of Landscape architecture, University of Ljubljana
} 
highest number of human needs and are more persistent than other buildings and do not serve anything that is secret or evil .... "Ivo Andrić

Quote of the most famous Bosnian writer Ivo Andrić, gives us a very unusual and acceptable description of the bridge.

A bridge can be defined as a bond which is romantic and realistic (of heart and mind), as a metaphor for the spiritual and material communication. The bridge is built, but it is also a building that continues to build communication. Bridges are structures that give rise to an unforgettable impression to people passing by. Since ancient times, the fate of the bridges is intertwined with the fate of people. Many significant events are connected with bridges, their construction, demolition and with their existence. Events around the bridges and the bridges themselves have inspired artists, stimulated legends and interesting stories of ordinary people.

Historically observed, the phenomenon of human need for water attracted, gathered and brought people together from all the parallels and meridians, but also as a natural barrier to contact of two sides which he also separated. The natural route of a streams or rivers presented a logical communications route for the movement of people, regardless of whether they were daily crossings from one shore to the other, or whether they ventures for which it is necessary to make any great effort, energy, ingenuity in order to achieve specific goals of that time or to achieve traffic communication exposed through migration of people, transport of goods, travels of different character, warfare,...

However, changes and progress of living conditions, the development of farming, higher rate of exchange of goods, the development strategy of war, gradually comes to positioned and thorough construction, which is, crossing over the barrier to the realization of which uses wood pulp, later stone mass, as basic materials for this purpose and, at the same time, pave the practical and useful rules of construction of bridge structures. The development process of bridge construction systems, as we look to historical sources, has been a long and slow.

The old builders equally well applied beam and console systems. Thanks to the experience of the old building that Etrurians, with a rich imagination, revealed the secrets of the structure of the vault, vaulting gradually finds application in the bridge construction and is being used as a basic structural supporting element of the stone bridge structures regardless of the range of arch structures and the overall size of the bridge structures.

Over time it has become a new impulse in creating and shaping the stone bridge constructions on the Balkan Peninsula, where along with the already known structural beam bridge building gets new impulse to the application of a wedge-shaped cut stone and radial directions reservoir coupling. These methods solved the problem of the side thrust of the vault, which is transferred to the poles, that is, column is being designed so that it can successfully accommodate the horizontal thrust of the vault. From such conception, Roman arch bridge building and architecture were brought to perfection and it was the basis for all other, later emerged, new bridge stone structures on the ground in Europe and the Middle East. 
The issue of greater range and dominant semicircular shaped arches caused, in addition to better treatment, usage of larger stone blocks - blocks throughout the constant thickness of the vault (CHABBOUH - AKŠAMIJA, 2009).

\section{MATERIALS AND RESEARCH METHODS - Materijal i metode istraživanja}

On the surface analysis of the status review of the literature, painting and literary works, old photographs and postcards, drawings and sketches, the typology of cultural landscapes will be explored, that is, bridges that were built during the Ottoman period in the figure of the cultural landscape in specific cities.

The research process started with the review of the historical bridges occurred in the Ottoman period, as well as with the analysis of some examples of situations in different cities.

Based on the review of old postcards and maps, mentioned examples were defined within the urban matrix.

In addition to the bridge at Buna, the study included the Arslanagic Bridge on the River Trebišnjica near Trebinje, the bridge on the coast of Žepa, the Old Bridge in Mostar, the bridge Kriva ćuprija in Mostar, the stone bridge "Kozija ćuprija" on the river Miljacka and the bridge Mehmed Paša Sokolović in Višegrad.

\section{RESEARCH AREA - Područje istraživanja}

Cultural landscape can be viewed as a large and complex historical building, neglected and devastated over the centuries, although not substantially different from the architectural heritage of urban spaces that has long been protected by national and international institutions (individual historical monuments, urban and rural units. ..). One of the founding members of the idea of cultural landscape is SAUER (1925), who, during twenties of the last century, provides one of the first, but also one of the clearest of definitions:

"The cultural landscape is more innovative in relation to the natural landscape when it comes to the term 'culture', where the culture is a starter of the idea, the nature a medium of its action, and landscape the result."

If it is determined that the culture is the starter of the ideas in the cultural landscape then it will consequently follow that it is a symbiotic relationship, active participation on the one hand (culture) and passive activity on the other (nature). This "passive activity" does not mean the inferiority within unity. Nature is a permanent carrier of the basic image of space where everything else is subordinated, and its existence is threatened by wrong human activities. At the same time the cultural landscape can be defined as a framed environment, horizon, from which man perceives nature, where significant change includes cultural creation. 
Identification with the first fruits of the landscape is socially conditional. Upon this is dependent relationship of society, as well as individual, to the space in which he lives (KUČAN, 2002).

In the 15th century Ottoman Empire comes to the limits of the medieval Bosnian kingdom. Recognizing the need for the development of urban planning, urban areas have begun to sprout and receive their basic form whose organization noticeable today.

Based on multiple factors, towns and fortresses on the territory of the former Yugoslavia, which was part of the Ottoman Empire, can be divided into three basic groups: coastal cities, towns and forts in the interior, and fortified monastery complexes.

Coastal cities often originate from the Ancient period. Over the centuries they were demolished, rebuilt and refurbished. Top fortified building within this structure is the citadel. The specific character of the cities in the interior was their military nature and position on the field, with a very good view of the surroundings. They were built on a rocky, inhospitable hills. Parts from which they are accessed are much better secured. As they were adjusted to the terrain, they ended up having an irregular basis.

Basic communication system that the Ottomans found in the former Yugoslav territories was the Roman, Byzantine and medieval. They complement him through construction of several bridges at all major intersections of roads and waterways, as well as the construction of hostels for people on the go - hans and caravanserai, at a distance of about forty miles, that is, the length that a wagon can cross in a day (VELIKANOVIĆ, 1900).

\section{RESULTS AND DISSCUSSION - Rezultati i diskusija}

There are bridges, small and large, built over small and large waters, with a name and no name or even with two names. There are bridges that are gone forever under reservoirs or demolished due to the requirements of the new era, and there are those who could and should stay.

There are bridges that are not built to be beautiful, but they can endure the burden and time, because there are some built on the water so the people could have solid ground underneath their feet so that they won't be overwhelmed by the water, the human foot, hoof horse and time.

Since time immemorial there is an unwritten rule: when a bridge builds a state and the army, then the bag opens wide, and a deed is done, great and permanent, and will the deed be beautiful, it depended on how much the builders have soul and meaning, and how it brings in its work. 


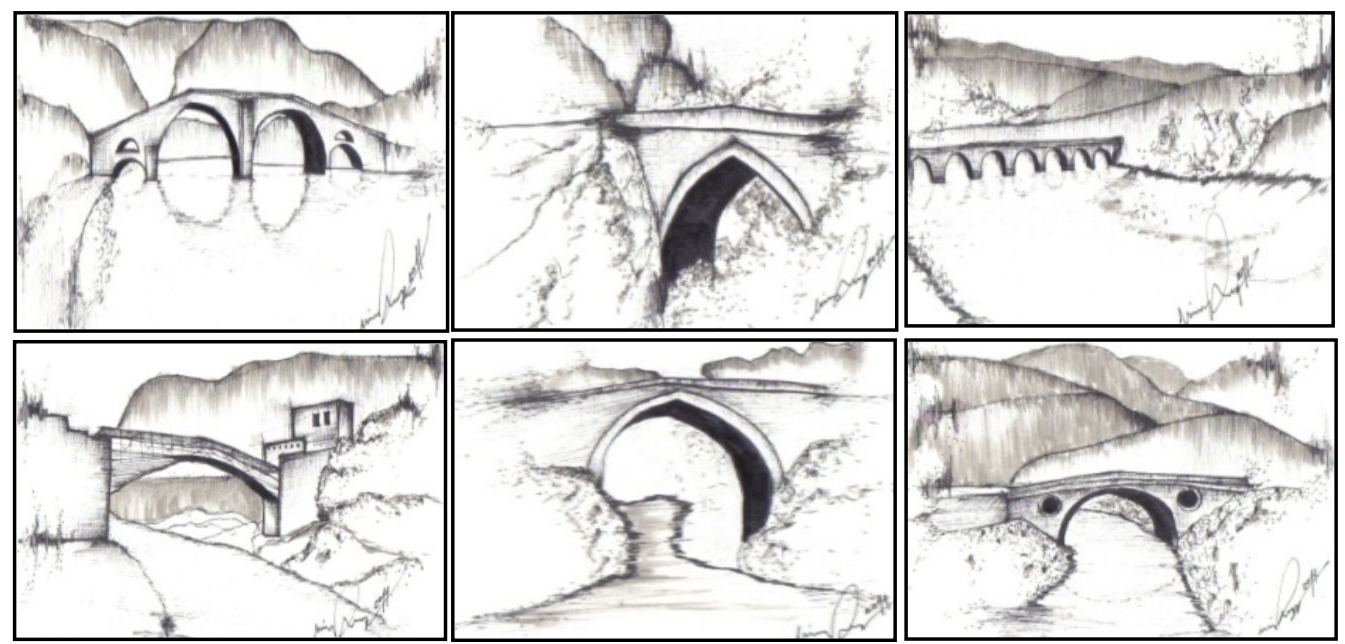

Picture 1. Bridges from the Ottoman period in Bosnia and Herzegovina (Author: Mirna Krpo) Slika 1. Mostovi iz Osmanskog perioda na području Bosne i Hercegovine (Autor: Mirna Krpo)

Inclusion of a country in the assembly of the Ottoman Empire begins a new era not only in the military - political, but also economic and cultural history of Bosnia and Herzegovina. Ruling system, religion, and other achievements of the Islamic Ottoman civilization are domesticating themselves increasingly, living areas reorganize under the scheme whose origins should be sought in the East, crafts and trade are developing, there is a need surfacing for a very diverse architectural constructions, sacred and profane, monumental and utilitarian. In that general socio economic reorganization, the state, primarily took care for the military - strategic facilities, amongst which bridges, especially on larger rivers and major regional communications, occupy an important place.

So, the bridge, as a facility, anticipates a number of elements, or elements of a wide range of economic, historical, sociological, architectural, which will reevaluate tomorrow, or some time to come. That is, the vision of today will become tomorrow's reality. The best example is the Old Bridge in Mostar, because it was designed by Mimar Hayruddin who was a visionaire, and didn't just look at a bridge as a transmuting communication, but he saw the bridge as part of tourism.

The 15th and 16th century was the era of the strongest Turkish invasion, the greatest economic prosperity (including great war spoils), and also the time of the most intense urbanization of the oldest settlements in Bosnia and Herzegovina.

No wonder that precisely in the sixteenth century, the major architectural achievements of the entire epoch were created along with the largest and most beautiful bridges.

Professors ČELIĆ (1998) and MUJEZINOVIĆ (1998) stated that the Turks mostly use old communication routes, set out in Roman times, exploited even during the Middle Ages. Although the strategic and economic importance of these 
communications in the new conditions got a new orientation in almost the opposite direction of the original Roman, but that does not mean that they were a necessary cardinal change of the communication network. The Era of adjustment comes in, whereby the deviations were observed primarily in detail, in the inclusion of new settlements in the basic communication routes (ČELIĆ, MUJEZINOVIĆ,1998).

Logic of choice of basic concept, that is, the bridge to one or more vault arches, which are given the natural conditions in a particular place. One vault is normal, logical and economical solution if the range is small, if the river is deep and torrent strong, if the coast is steep and high, if the structure of the coastline is solid and strong enough to accept the stress oblique forces.

Even today, when the stone bridges belong to history, this basic rule, that is, the steep coastline with a deep trough links, in the coasts with braced arched structures, and the broad river poured in a horizontal landscape solves the frame through a series of poles.

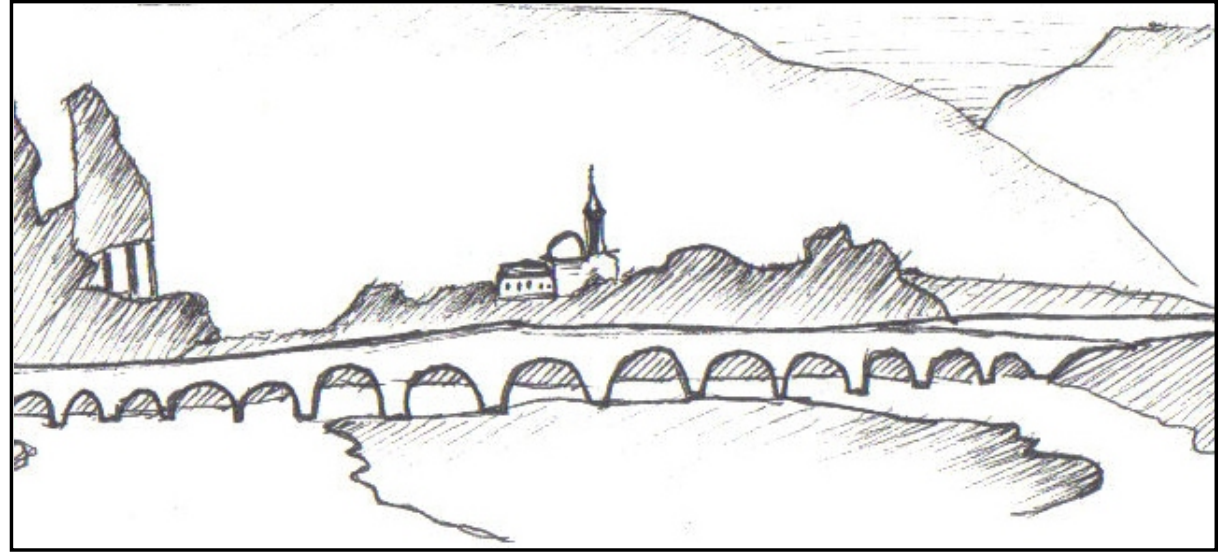

Picture 2. Sketch - A series of arches in a certain rhythm are logical and economical solution to a wide river (the bridge over the Buna village Buna) (Author: Mirna Krpo)

Slika 2. Skica - Niz svodova u određenom ritmu logično su i ekonomično rješenje na širokoj rijeci (most preko Bune u selu Buni) (Autor: Mirna Krpo)

Those old Turkish bridges were built solidly of cut stone on the strong pillars in the river bed and toward the center they were elevated for rapid flow of water away from pavement. Bridges connected the coast and represented the most valuable part of the transport network. Many of these objects are also built of wood. Complicated, more expensive and less numerous were the bridges of stone, many of which are up to date, partially or completely, saved and dozens of others were built from the 15th to 19th century.

The most beautiful bridges were built in the second half of the 16th century during the reign of Sultan Suleyman the Magnificent and his great vizier Rustem Paša and Mehmed Paša Sokolović. Sokolović bridge on the Drina in Višegrad is a work of 
the greatest Turkish architect Kodža Mimar Sinan, the Old Bridge in Mostar of his student Mimar Hajrudin.

Among these builders, the one that was definitely the most skilled and exemplary was Kodža Mimar Sinan, who, after all, started his architectural career with a similar work; construction of three large ships to transport armies across the lake to the east of outside Anadolu during the days of the crusade against Persia. Some stone bridges, of the Turkish period, emphasize the right shape and master craftsmanship. Simpler builds were performed, especially in later centuries, by local builders.

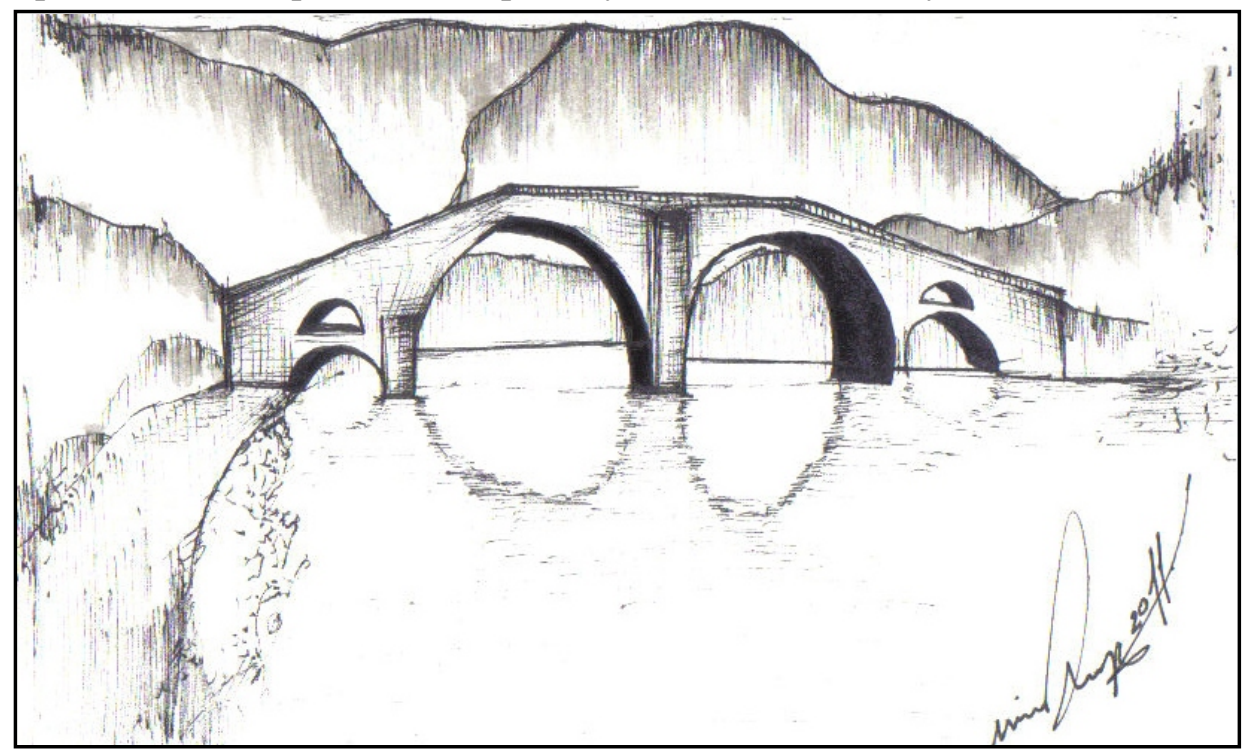

Picture 3. Sketch - Arslanagić Bridge on the River Trebišnjica near Trebinje made 1574.year (Author: Mirna Krpo)

Slika 3. Skica - Arslanagića most na rijeci Trebišnjici kod Trebinja napravljen 1574.god. (Autor: Mirna Krpo)

The bridges have been written about by many famous and less famous and renowned writers, travel writers and poets. Many bridges were celebrated in songs or described in the literature. There are many stories about them, poems, legends and anecdotes, which are discussed below.

So if we go back to the past, to 15th and 16th century during the Ottoman period, we will notice that there were true lovers of scenery, traveling and describing in detail its beauty. At that time, the only built railroads and roads, were, as a miracle, admired by many and nature seemed untouched and therefore even more beautiful. That unspoiled nature was spoiled only by occasional trains, postal carriages, assorted cars, carts and herds of cattle.

Untouched nature is an authentic or original setting of an environment. The bridge is represented in this period as a bond between civilized spaces and unspoiled 
nature, it was a nexus of two hands, which allowed the man, the product of civilization, to get across to the pristine nature.

Since Bosnia and Herzegovina is largely mountainous country, major roads and railway routes followed the line of most of its beautiful rivers, whether they meandered green valleys or pierced impassable canyons.

Picture of a bridge in landscape can be best seen from the descriptions of the travel writers during their travels. So the most realistic picture of the bridge at the mouth of Žepa, which would encourage imagination and delight in the ambience which was noted by MICHEL (1912) and his impression was described as follows:

"A few feet away we stopped before a deep trough of Žepa and we saw quite up close in front of us a beautiful stone arch, which led to the other side of the chasm. This wild and noble building work leaves a deep impression twice. You can barely discernible it on a rocky ravines where its construction starts, from mountain rocks, grows a Gothic stone arch so harmoniously that might lead one to believe that the rocks by themselves overcome the abyss " (ČELIĆ, MUJEZINOVIĆ,1998).

The steep, almost vertical shores of Žepa and narrow gorge through which the river makes its way towards its estuary conditioned the bridge with one hole, bent pointed arch with a span of 10-20 meters. The bridge in the landscape looks like bracings between two almost vertical rocky shores. It is very steep right bank, while the profile of the left one is in its upper part of the slope.

Finding a support directly on steep coastal cliffs, and at different altitudes has limited the bridge growing, from rock to rock, which left a key impression of fragile buckles on collision of two geometric growths, which we can see from the following drawings:
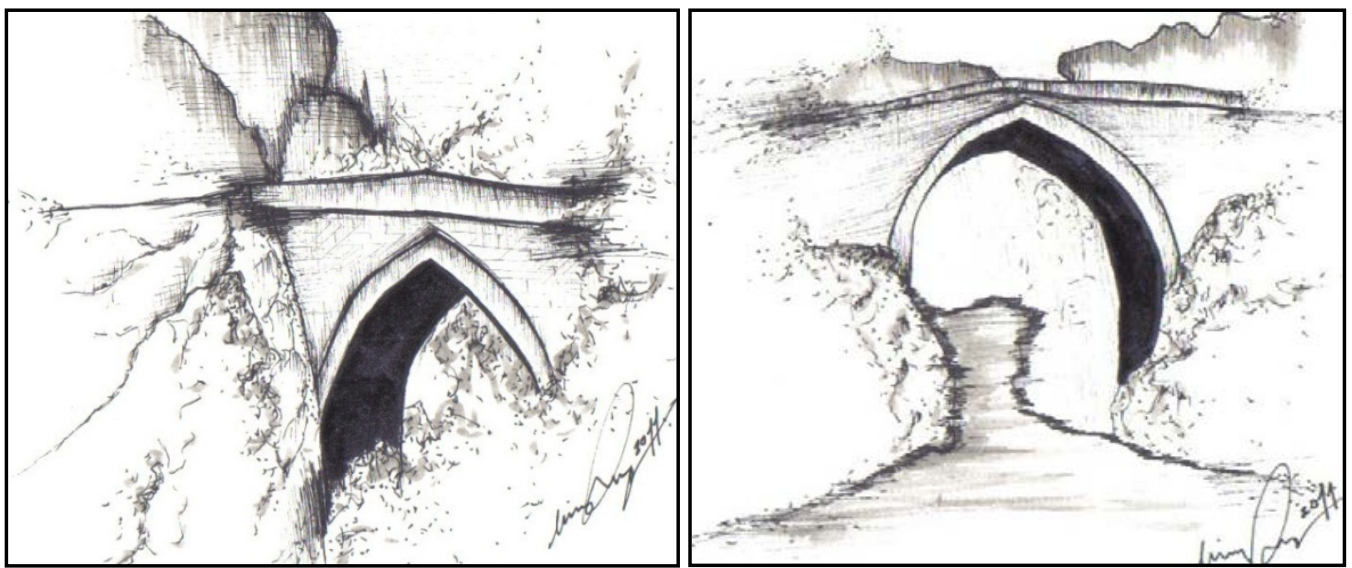

Picture 4. Sketch - Bridge on the coast of Žepa (Author: Mirna Krpo)

Slika 4. Skica - most na obali Žepe (Autor: Mirna Krpo) 
The area around Mostar was already, during Roman times, quite densely populated. Especially around the mouth of Buna, where they found numerous archaeological remains. Traces of Roman roads, around Mostar indicate that there must have been one path crossing over Neretva river, although there are no firm indications on which we can for a basis of whether that crossing over was in Mostar, or something upstream or downstream.

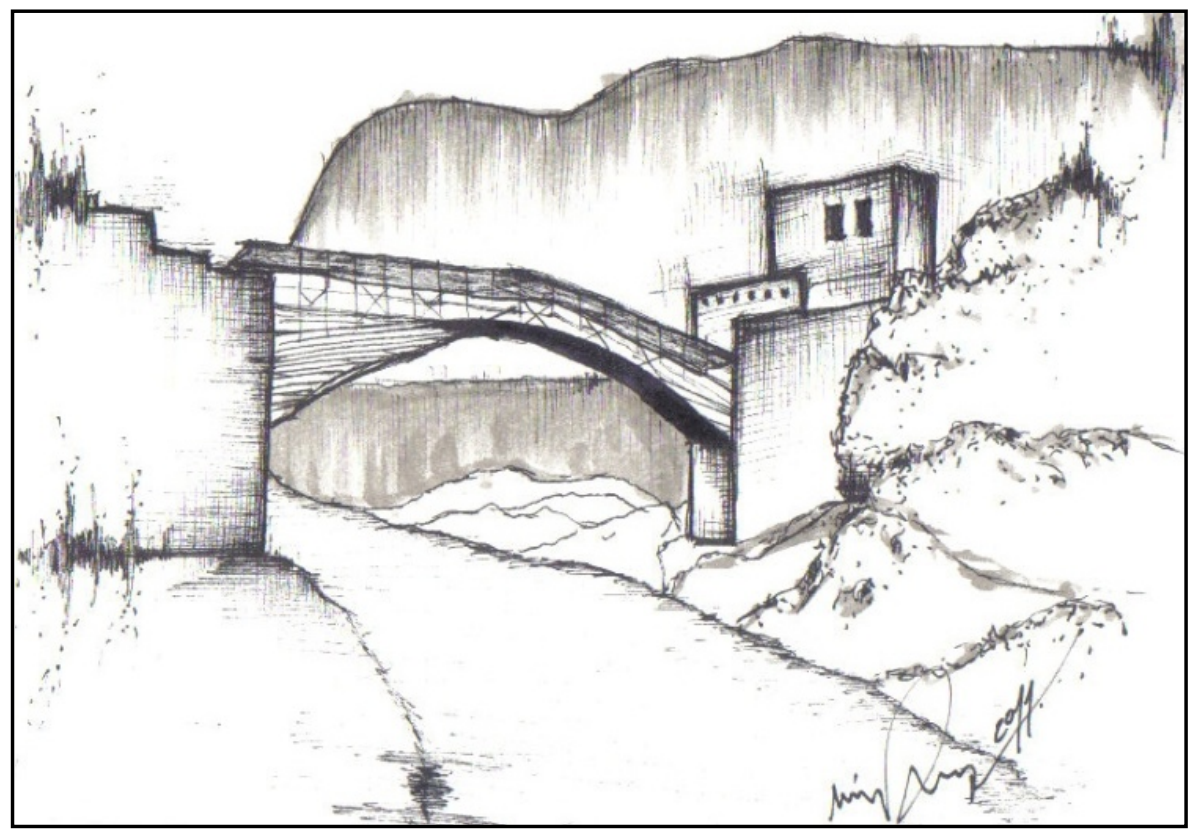

Picture 5. Sketch - The wood bridge which is made before the real Old bridge in Mostar (Autor: Mirna Krpo)

Slika 5. Skica - Drveni most koji je prethodio Starom mostu u Mostaru (Autor: Mirna Krpo)

While it is clear that the bridge over the Neretva emerged, primarily due to the regional traffic needs, his appearance conditioned the rise of its gradual concentration of the population. Medieval bridge was wooden, weak and shaky, and Turks used it for their military operations on the right side of the river, still in western Herzegovina. Like other foreign passengers who crossed over the bridge, just as did the Turkish traveler ČELEBIJA (1996) during '40s of the $16^{\text {th }}$ century, saw the bridge harmony and professional skills of its architects. He also noted the bridge and harmony with the surrounding environment, and he enthusiastically made a following notation of it:

"When this bridge looked at from a distance, it looks like a circular arc out of which an arrow was just shot out, so it stopped in that motion. Current architectural taste, precision and elegance, which is introduced into this beautiful stone artifact, wasn't showed by any old house builder. Since this old bridge was built some viziers, leaders and dignitaries started coming to see it. And while sitting in a shack, they look at how 
many brave children are ready on the edge of the bridge. And when they get a running start, they jump off a bridge, dropping down to the river and flying in the air like birds, each one of them preformed some acrobatics " (ČELEBIJA, 1996).

The study analyzes that were done by NEIDHART (1942) and ČELIĆ (1998) have written: "This impressive arch with its towers, buildings and roofs were like grayish to gray, unfurnished, as some icicles, stabbed around, it seems, within the wild landscape of the Neretva and rubble, a harmonious whole, that, by abstracting the details, all together, looks like a big rock on which the crystals were grown, but also an area in which a man builds for his needs. Nevertheless, it is all a formation of a heavy and painful past, where a man, in the eternal struggle for survival and self-preservation (wars, slavery, tribal hatred, etc.) knew how to enter the stone himself, his temperament, his psyche, his cheerfulness. "

Analyzing the environment in which it was incorporated into the bridge towers, the authors of these studies have asserted a listing of historical elements, clearly historical periodicals of his life, and the dominance of each historical period through which he passed. The advent of a new era and new architectural achievements anarchy broke the continuity and harmony of the urban historical complex accomplished during the past century.

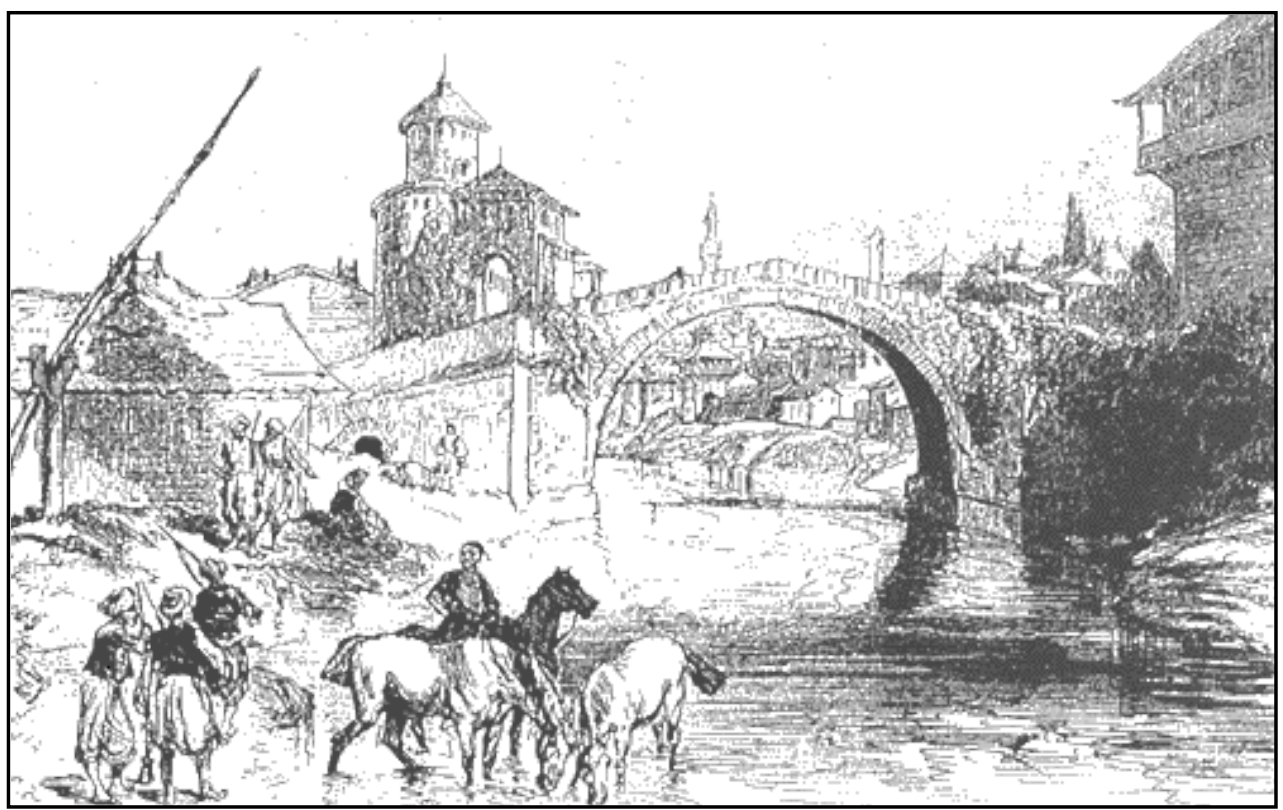

Picture 6. Drawing Old Bridge published in "Illustrierte Zeitungen", Leipzig, during 1875. year Slika 6. Crtež Starog mosta objavljen u "Illustrierte Zeitungen", Leipzig, za vrijeme 1875. godine 
Travel writer MicheL (1912) during the Austro-Hungarian period, describes the area of the Neretva river and the bridge:

"Every year, during the colder months, gulls visit this building, with special reverence and devotion. Lurking, near the mouth Radoblje, humbly, each other, committed to looking upwards towards the stone arch bridge, or take off in a tireless, brilliant movement around the amazing arch bridge, whose beauty intoxicates them. Some gulls suddenly clap together their long wings and float around as small bright birds, sitting on the green water of the Neretva, head dive into the water for bread. While standing on this bridge and watching the gulls I had to think, maybe these birds in high crucified harbor bridge can't see anything other than a massive petrified seagull. Once upon a time this gull flew through here for the first time, right here he paused, mesmerized by the beauty of this piece of country, forgot to clap his wings and so he turned to stone, touching with his wingtips the banks of the river" (MICHEL, 1912).

On the river Radobolja, about 150 yards upstream from its confluence with the Neretva, there is a small stone bridge with one arch, which is known as the "Crooked Bridge". Across the bridge in the course of a long period of Turkish unfolded live traffic, because for a long time it was the only communication facility for crossing over Radobolja in its lower course. Until the construction of railways through Mostar during 1884. year, this bridge was on the main road running from south to north and vice versa. Michel saw image of Radobolja in the following way:

"Source of Radobolja provides an image of lavish abundance. With unexpected fullness, this valuable source springs from the hills. At first it strives with waves in height.

On one side it faces the huge mountain rampart, many times higher than the height to which water resources can reach out, search your way to the opposite side and a free valley that leads to Mostar can be found. "

MicheL (1912) also gives us a picture of the landscape in which Radobolja with the Neretva River in addition to its subordination seeks to resemble the Neretva. Indeed, despite all the differences we find many similarities between these two rivers (Michel, 1912). One could say that the magnificent baroque of Neretva is being transformed by Radobolja into charming rococo.

Radobolje regulation and construction of railway bridges over it, stopped the people almost completely from using the Crooked Bridge because it is deep in the riverbed of Radobolja and access to it, from both sides, is ineligible.

In the sixteenth century, or even earlier, the bridge was able, at this place, to have primarily regional-strategic importance, because of the suspension bridge over the Neretva, there was established a direct traffic link in the direction of the western and southwestern Herzegovina. 


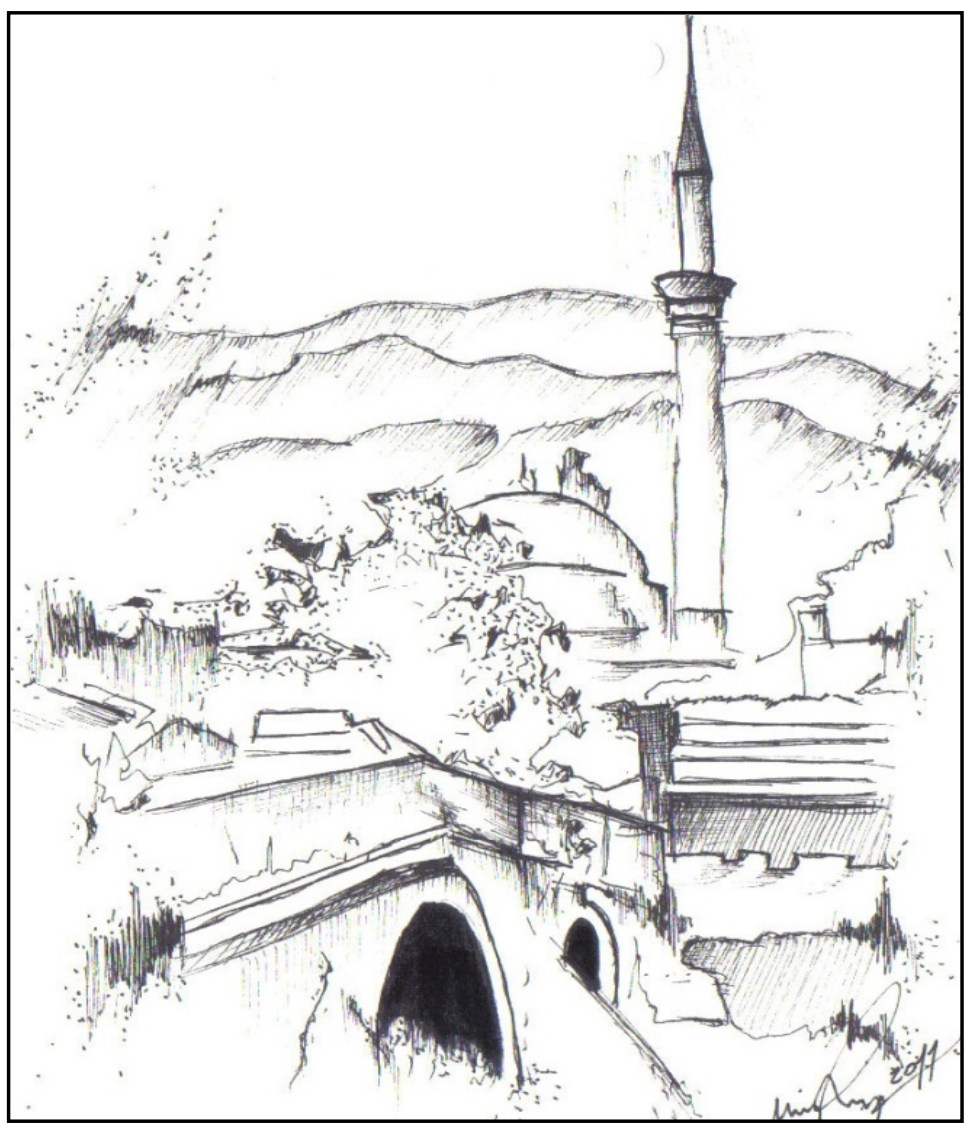

Picture 7. Sketch - stone bridge with one arccalled "Crooked Bridge"(Author: Mirna Krpo) Slika 7. Skica - kameni most na jedan luk pod imenom "Kriva ćuprija” (Autor: Mirna Krpo)

The basic concept Crooked Bridge is a bridge with one multi-directional aperture and ascends from both sides toward the middle. Onion is, if we leave aside less deformation, fully proper semicircle (ČELIĆ, MUJEZINOVIĆ,1998).

In the Ottoman era of Bosnia, Kozija ćuprija was the place where they welcomed imperial governors - viziers. Each new vizier had a brand new welcoming committee on the bridge.

Before him, all the prominent people in Sarajevo would come out, and assemble to the ordinary people because it was one of the highlights of the event. Whoever built on the Kozija ćuprija over Miljacka had a lot of soul in his body and his eyes were full of measure - he knew how to handle stone to stone bridge building and made it look like a beautiful book which he didn't even sign because during some periods, in some areas, people didn't sign neither the books nor the stone sculptures and bridges. 


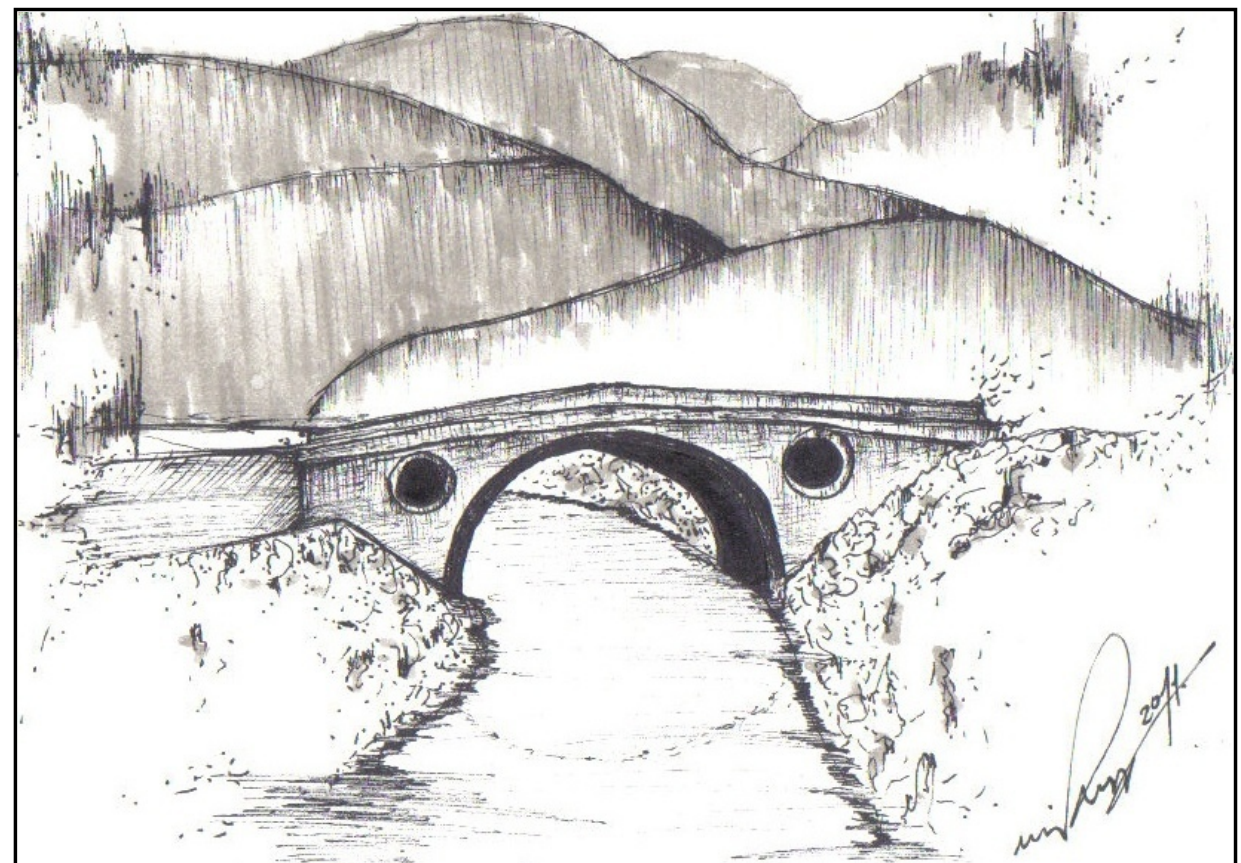

Picture 8. Sketch - stone bridge "Kozija ćuprija on the river Miljacka (Author: Mirna Krpo) Slika 8. Skica - kameni most "Kozija ćuprija” na rijeci Miljacki (Autor: Mirna Krpo)

The Mehmed Paša Sokolović bridge in Višegrad represents one of the most monumental works. Part of the bridge over the river is consisted out of eleven arched openings, one of which is the final hole on the right bank, leaning on two retaining walls with the smallest range.

At the middle of this bridge stood a wooden tower for which there is no known date of origin, and which was demolished in 1886th year. The tower represented a guard-house underneath which who was a passage, which was closed with strong oak doors on both sides.

The middle of the bridge, called the gate - the sofa was extended and soon became a popular meeting place for people from Višegrad and surroundings, a relaxed state that is still typical in modern Turkey and most of the Balkan.

Travel writer Renner experienced coasts like Kai, he sees broad majestic rivers, a big old bridge, across the bridge are remains of the ruins of the old Ottoman caravanserai, and next to them are barracks"(VELIKANOVIĆ, 1900). 


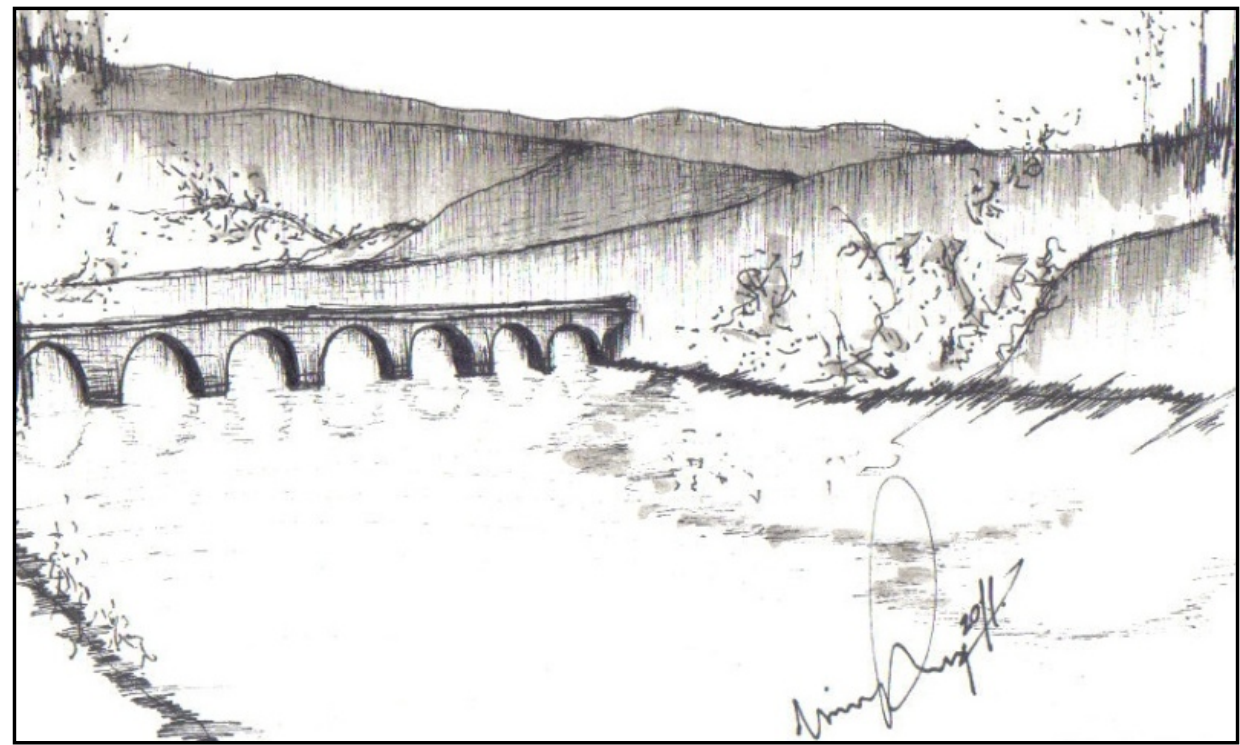

Picture 9. Sketch- The bridge Mehmed - paša Sokolović in Višegrad (Author: Mirna Krpo) Slika 9. Skica - Most Mehmed-paše Sokolovića u Višegradu (Autor: Mirna Krpo)

\section{CONCLUSIONS - Zaključci}

Landscape is not only a natural ability and specific segment of the living nature, the landscape is a shortened and condensed space inhabited by natural forms and motifs from nature, but subordinate to the standards of visual reflection with all elimination, additions and transformations of relations and sizes.N atural forms in the Ottoman period are stylized as relief boulders, and building bridges presented ideas about statics and equilibrium mass and volume that is held together by some unknown force. The whole appearance of the landscape is subordinate to the play of a cosmic balance, in which reality is transformed and compressed to meet the demands of trade, transport, disposition and aesthetic relationships.

Man's relationship with nature, since it is not just physical or just psychological, sums up in itself a number of conceptual, aesthetic and philosophical components, which form the spiritual form of the epoch and the vision of the world transposed in that period.

But in all style formations and all historical epochs, in landscape, we recognize the spirit of time and man's relationship with the values and ideals of the era; landscape everywhere is a huge spiritual screen on which are projected contours of the world and its driving forces.

An analysis of the historical development of bridges leads us in history and there we can clearly recognize that what is a confirmation based on the maximum 
certificate of utilitarianism bridges. The man's need to bridge the river channel or gully the most primitive solution that is a simple beam trunk leaning on the two coasts, over the complex of wooden structures, knowledge of the application of different materials that provides various forms has led us to the discovery of construction.

Through the presented examples we can confirm the universality of the object that without a certain stylistic affiliation, built by the hands and the knowledge of the local builders, however, don't disturb the landscape, but on the contrary, they complement each other, and create a special harmony.

Bridges in the general image of the landscape represented a decor and the stage that was used primarily for transport and trade. Picture of this landscape is not dehumanized, there are traces present of man and his works.

\section{REFERENCES - Literatura}

AKŠAmiJA ChABBouH, L. (2003): Arhitektura svrhe, str.28, Sarajevo.

ČElić, Dž., MuJeZINOVIĆ, M. (1998): Stari mostovi u Bosni i Hercegovini, str. 23, 27, 205, 252, Sarajevo.

ČelebiJA, E. (1967): Putopis, prijevod Šabanovć Hazima, str. 471, Sarajevo

GrabriJAN, D., NeIDHARDT, J. (1942): Sarajevo i njegovi trabant.

KUČAN, A. (2002): Krajina kot nacionalni simbol, str. 38, Ljubljana.

Michel, R. (1912): Alte Brucken in Bosnien und der Herzegovina, Fahrten in den Reichslanden, str. 65, Wien.

SAUER, C. O. (1925): The Morphology of Landscape. University of California, Publications in Geography 2.

VeliKanović, R. (1900): Herceg - Bosnom uzduž i poprijeko, Mitrovica.

\section{Sažetak}

Ovaj rad, prvenstveno, ima za cilj da obuhvati i analizira odabrane mostovne kamene konstrukcije u slici kulturnog pejzaža, koje su nastale u okviru Osmanskog perioda, na teritoriji današnje Bosne i Hercegovine,

Ove mostovne konstrukcije, bez obzira da li su bile smještene direktno ili na priključnim trasama uz navedenu rimsku trasu, kao i na funkcionalno - konstruktivnu minijaturnost, odnosno stilsko - estetsku neuravnoteženost imaju ulogu određene popune praznina koja se u Bosni i Hercegovini osjeća u poznavanju razvoja te vrste građevinskih objekata. 
Analiza historijskog razvoja mostova vodi nas u najstarija vremena i tu jasno prepoznajemo ono na čemu se temelji potvrda o maksimalnoj utilitarnosti mostova uopće.

Preko prezentiranih primjera potvrđujemo svevremenost objekta koji bez određene stilske pripadnosti, a izgrađeni rukama i znanjem domaćih graditelja, ipak ne narušavaju pejzaž, nego upravo suprotno, oni ga nadopunjuju, i stvaraju posebnu harmoniju prostora. 